\title{
Two New Records for Spider Mite Fauna of Turkey, Tetranychus kanzawai Kishida and Eotetranychus rubiphilus Reck (Trombidiformes: Tetranychidae)
}

\author{
Yunus Emre Altunçc,a, Rana Akyazı 1,b,* \\ ${ }^{I}$ Plant Protection Department, Faculty of Agriculture, Ordu University, 52200 Ordu, Turkey \\ ${ }^{*}$ Corresponding author

\begin{tabular}{l|l}
\hline A R T I C L E I N F O & A B S T R A C T \\
\hline Research Article & $\begin{array}{l}\text { Two new spider mites, Tetranychus kanzawai Kishida and Eotetranychus rubiphilus Reck } \\
\text { (Trombidiformes: Tetranychidae) were recorded for Turkish phytophagous mite fauna. While E. } \\
\text { rubiphilus was obtained from Prunus domestica L. and Prunus cerasus L. (Rosaceae), T. kanzawai } \\
\text { was found only on P. domestica in different municipalities of Ordu province, Turkey. }\end{array}$
\end{tabular} \\ Received : $12 / 10 / 2018$
}

Accepted : 20/07/2020

Keywords:

Tetranychus kanzawai

Eotetranychus rubiphilus

Tetranychidae

Spider mites

Prunus

yunusemrealtunc@odu.edu.tr (iD) https://orcid.org/0000-0001-5539-552X

|b@ranaakyazi@odu.edu.tr

http://orcid.org/0000-0002-0054-4222

(c) () () (9) This work is licensed under Creative Commons Attribution 4.0 International License

\section{Introduction}

Tetranychid mites represent major pests in agriculture. They cause severe symptoms and yield losses by feeding in many crops of economic importance worldwide. To date, 1321 species of tetranychid mites belonging to about 86 genera have been identified all over the world. The genera Eotetranychus Oudemans, comprise 200 species and Tetranychus Dufour 154 species (Migeon and Dorkeld 2019).

According to Migeon and Dorkeld (2019), five species of Eotetranychus are recorded from Turkey. These species are E. carpini (Oudemans) (Onucar and Ulu 1988; Uysal et al. 2001), E. coryli Reck (Ozman and Cobanoglu 2001), E. populi (Koch) (Duzgunes 1965), E. pruni (Oudemans) and E. tiliarium (Hermann) (Duzgunes 1963).

The genus Tetranychus are also represented by 5 species in Turkey (Migeon and Dorkeld 2019). They are as follows; Tetranychus evansi Baker \& Pritchard (Kazak et al., 2017); Tetranychus solanacearum Cobanoglu \&
Ueckermann (Cobanoglu et al. 2015); Tetranychus tumidellus Pritchard \& Baker (Duzgunes 1959); Tetranychus turkestani (Ugarov \& Nikolskii) (Duzgunes 1954; Uysal et al. 2001; Ozsisli and Cobanoglu 2011) and Tetranychus urticae Koch (Duzgunes 1954; Aydemir and Toros 1992; Altincag and Akten 1993; Uysal et al. 2001; Ozsisli and Cobanoglu 2011; Kasap et al. 2014).

Although, a total of 10 species of Tetranychus and Eotetranychus are reported from Turkey by Migeon and Dorkeld (2019), Tetranychus desertorum Banks (Duzgunes 1962) and Eotetranychus uncatus German (Yanar and Ecevit 2005) were omitted by these authors.

This paper reports two new records of tetranychid mites belonging to the genera Eotetranychus and Tetranychus for the Turkish mite fauna. Additionally, measurements $(\mu \mathrm{m})$ of the Turkish specimens (only the range), information regarding collection details, habitats, hosts and world distribution are also presented here. 


\section{Materials and Methods}

Mite surveys were carried out between May and November in plum (Prunus domestica L.) and sour cherry (Prunus cerasus L.) (Rosaceae) orchards located in Akkuş, Altınordu, Fatsa, Perşembe, Ünye municipalities of Ordu province of Turkey in 2016-2017. Leaves were taken from different parts of the tree canopy. The samples were put into paper bags placed inside plastic bags, labeled, and transferred to the laboratory. The mites were collected with a 0 or 00 paint brush under a stereomicroscope (Leica S8 APO) directly from the leaves. Mites were cleared in lacto-phenol, mounted in Hoyer's on microscope slides and dried for 5-7 days in an oven at $50^{\circ} \mathrm{C}$ according to the method of Krantz and Walter (2009).

Tetranychid mites were identified to species level using the relevant identification keys such as Auger et al. (2013), Zhang (2003), Seeman and Beard (2011), Maric et al. (2017) and observing key characters such as shape of aedeagus. Predatory mite species which were together with tetranychid mites on Prunus leaves were also collected. The identification of predatory mites was also performed using the available keys such as Cobanoglu (1989a, b, c; 1993a, b, c, d), Faraji et al. (2011), Doker et al. (2016) for phytoseiid mites and Ueckermann (2013), Ripka et al. (2013) for tydeoid mites.

Identifications and illustrations were made with a Leica DM 2500 phase contrast microscope equipped with a drawing tube. Measurements were done using Leica Application Suite (LAS). The identification of tetranychid species at the species level was made by Dr. Philippe Auger (INRA, France). The mite specimens were deposited in the Mite Collection at the Ordu University, Agricultural Faculty, Plant Protection Department, Ordu, Turkey.

All measurements are given in micrometers $(\mu \mathrm{m})$ with the mean followed by minimum and maximum values in parentheses. The setal nomenclature used in this study follows Lindquist (1985).

\section{Results}

Family Tetranychidae Donnadieu

Genus Tetranychus Dufour

Tetranychus kanzawai Kishida: 105

Synonyms (Migeon and Dorkeld 2019):

Tetranychus hydrangeae Pritchard \& Baker

Tetranychus japonicus Hotta

Examined material: Two males were obtained from plum leaves in Ordu province of Turkey; Akkuş, 4048'4.12" N, 3656'22.18" E, 1103m, 05.08.2016, $1 \delta^{\wedge}$ (P. domestica); Akkuş, 4046'4.59" N, 3656'31.07" E, 1224m, 05.08.2016, $1 \sigma^{\hat{\sigma}}$ (P. domestica).

\section{Description}

Male (n: 2) (Figure 1)

Body: Body length 313-320 excluding and 369-389 including gnathosoma. Dorsal setae measurements as follows: $v_{2}$ 51-52, $s c_{1}$ 60-83, $s c_{2}$ 54-57, $c_{1}$ 71-75, $c_{2}$ 68-74, $c_{3}$ 60-61, $d_{1}$ 75-77, $d_{2}$ 70-73, $e_{1}$ 69-72, $e_{2}$ 68-70, $f_{1}$ 56-57, $f_{2}$ 48-51, $h_{1}$ 17-19.

Gnathosoma: Spinneret length on palp tarsus 5.5. Peritreme curled distally (Figure 1c).
Legs: Length of legs (excluding coxae) and leg setal count as follows (solenidion provided in parentheses):

Leg I; 218-232, $2-1-10-5-9+(4)-13+(3)+2$ duplexes;

Leg II; 181-183, 2 - 1 - 6 - 5 - 7 - $13+(1)+1$ duplex;

Leg III; 176-177, 1 - 1 - 4 - 4 - 6 - 9+ (1);

Leg IV; 206-210, 1 - 1 - 4 - 4 - 7 - $10+(1)$.

Empodia I uncinate (claw-like) with dorsal spur, II-IV with proximoventral hairs (Figure 1a).

Aedeagus: Knob of aedeagus rounded anteriorly and pointed posteriorly (Figure 1b). Knob twice width of neck (5.6/2.2 $\mu \mathrm{m}$; knob/neck). Dorsal surface of knob slightly convex.

Remarks:

T. kanzawai is known as kanzawa spider mite or tea red spider mite. Females are carmine red in summer and striae form a diamond-shaped pattern between setae $e 2$ and $f 1$ (Ehara, 1956; Seeman and Beard, 2011).

Females oviposit 40-50 eggs during their life-span on the undersurface of leaves. The optimum temperature range of this species is between $20^{\circ} \mathrm{C}$ and $25^{\circ} \mathrm{C}$. At $16^{\circ} \mathrm{C}$, females enter diapause (Zhang 2003) and overwinter as such (Osakabe 1967).

This species occurs in the Palearctic, Oriental, Neotropical, Nearctic, Australasian and Afrotropical regions on 190 hosts especially on Morus genus. It is present in neighbor countries of Turkey such as Greece and Iran (Migeon and Dorkeld, 2019).

$T$. kanzawai resembles red form of $T$. urticae but differs in shape of male aedeagus with $T$. kanzawai having a much large knob (Ehara, 1956; Zhang, 2003).

T. kanzawai and T. urticae are polyphagous spider mites. They often co-occur on the same plant specimen. However, T. urticae in Japan is observed only in agroecosystems where predators are less abundant, whereas $T$. kanzawai lives on wild plants where predators are abundant. Because, it is known that $T$. kanzawai potentially encounters predators more frequently than $T$. urticae does (Murase et al., 2018).

In Asia and especially in Japan, this spider mite is one of the most serious pests (Nishimura et al., 2007). Phytoseiulus persimilis (Anthias-Henriot) (Mesostigmata; Phytoseiidae) controls T. kanzawai in vineyards. Neoseiulus fallacis (Garman) (Mesostigmata; Phytoseiidae) is effective on tea (Zhang 2003). It is also associated with Neoseiulus longispinosus (Evans) (Zhang 2003) and Neoseiulus womersleyi (Schicha) (Mesostigmata; Phytoseiidae) (Murase and Fujita 2018). Besides predator mites, T. kanzawai can also be controlled by predatory insects. Oligota flavicornis (Boisduval \& Lacordaire) (Coleoptera; Staphylinidae), Scolothrips indicus Priesner (Thysanoptera; Thripidae), Mallada basalis (Walker) (Neuroptera; Chrysopidae) and some species of Orius (Heteroptera; Anthocoridae) are most effective predators against this spider mite (Zhang, 2003).

In this study, T. kanzawai was collected together with Neoseiulella tiliarum (Oudemans) and Typhlodromus rhenanus (Oudemans) (Mesostigmata; Phytoseiidae) species on $P$. domestica. These predatory species might be potential control agents of $T$. kanzawai. Therefore, studies to evaluate their effectiveness to suppress $T$. kanzawai population are recommended. 

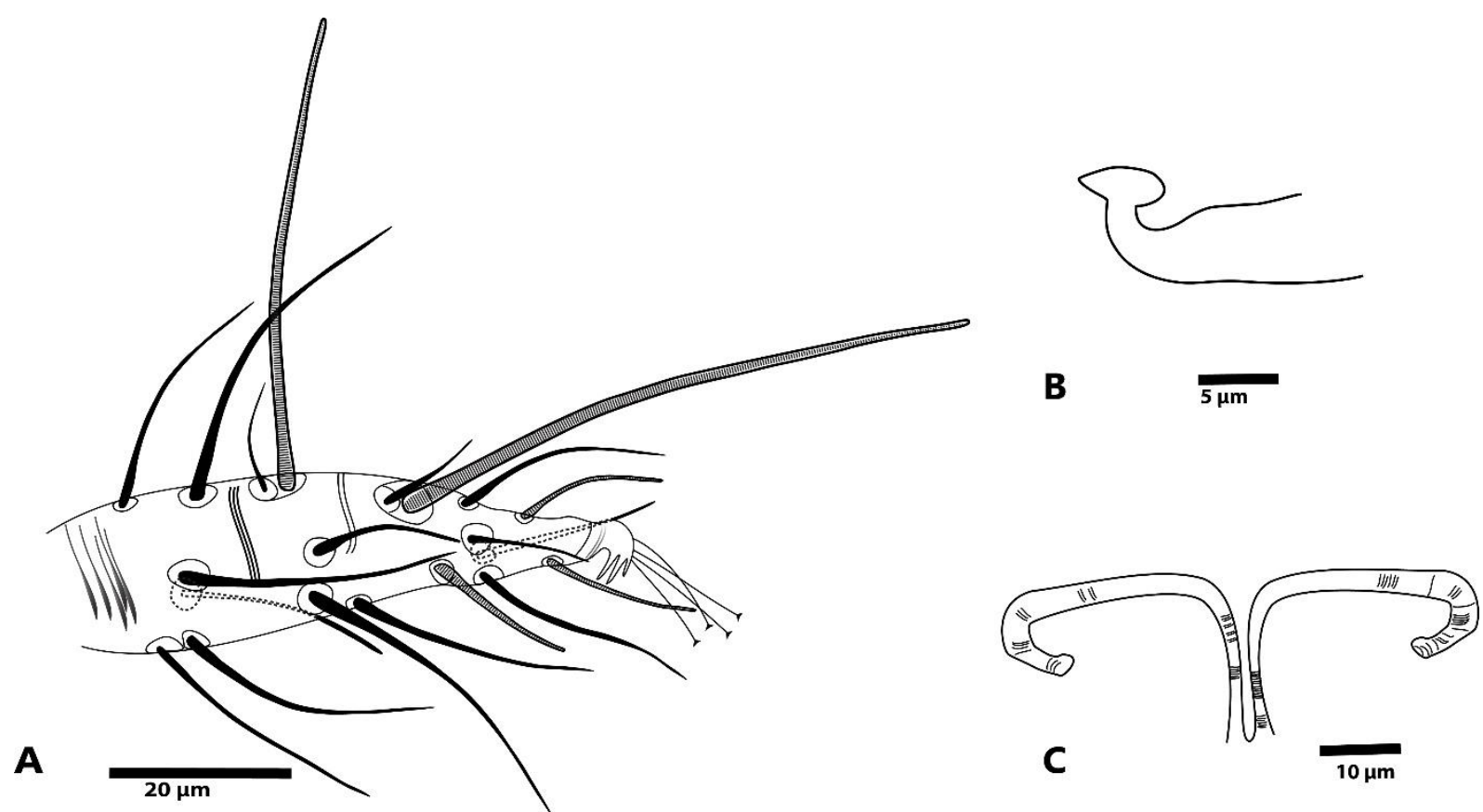

Figure 1. Tetrancyhus kanzawai male; tarsus I (A), aedeagus (B), peritreme (C)

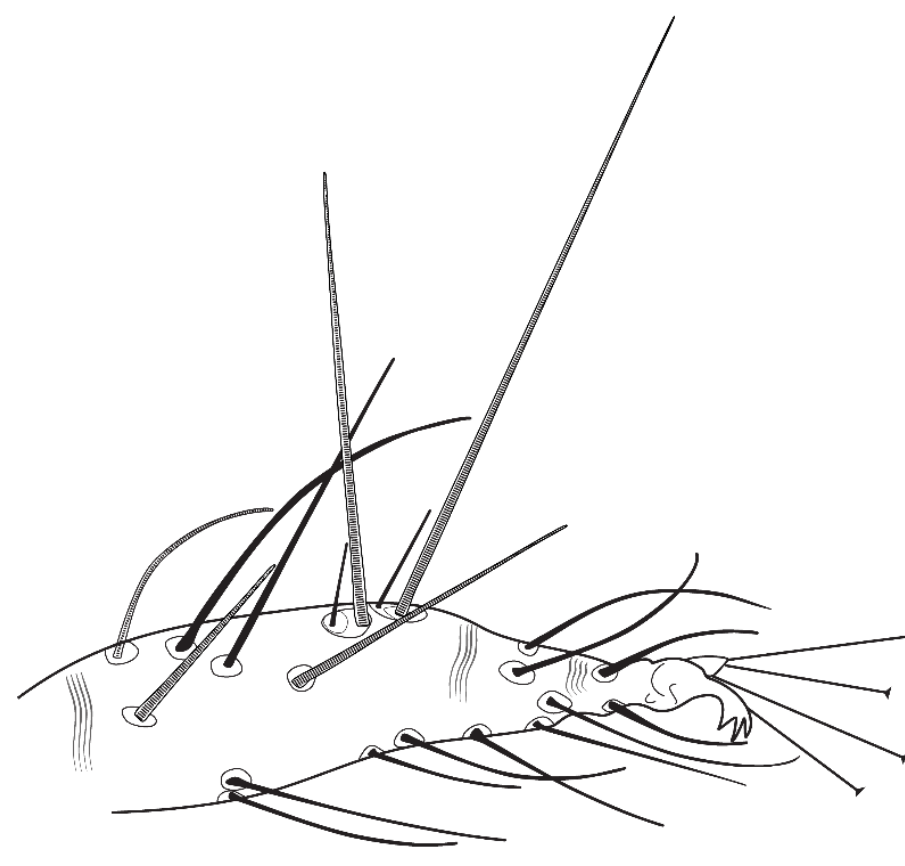

A

$$
20 \mu \mathrm{m}
$$

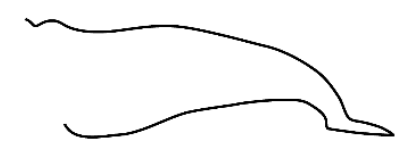

$\mathbf{B}$

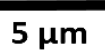

Figure 2. Eotetranychus rubiphilus male; tarsus I (A), aedeagus (B), peritreme (C)

\section{Genus Eotetranychus Oudemans}

Eotetranychus rubiphilus Reck; 447

Synonym (Migeon and Dorkeld 2019):

Schizotetranychus (Eotetranychus) bakurianensis Reck Schizotetranychus (Eotetranychus) luteolus Livshits and Mitrofanov

Schizotetranychus (Eotetranychus) rubiphilus Reck

Examined material: 22 males were obtained from plum and sour cherry leaves in Ordu province of Turkey; Fatsa, 4056'39.72" N, 37³5'19.86" E, 453m, 14.06.2016, $1 \sigma^{\lambda}(P$. domestica); Fatsa, 4059'59.92" $\mathrm{N}$, 37³0'37.72" E, 22m, 29.06.2017, 3ठิ (P. domestica); Altınordu, 40 58'1.48" N, 3745'44.25" E, 302m, 29.06.2016, 1ठิ (P. domestica); Altınordu, 4056'7.59" N, $38^{\circ} 0^{\prime} 14.81 "$ E, 387m, 29.06.2016, 20 (P. domestica); Perşembe, $41^{\circ} 5^{\prime} 9.65^{\prime \prime} \mathrm{N}, 37^{\circ} 38^{\prime} 12.30^{\prime \prime} \mathrm{E}, 5 \mathrm{~m}, 21.06 .2016$,

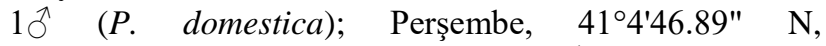
37³9'27.18" E, 224m, 21.06.2016, $1 \delta^{\Uparrow}$ (P. domestica); Perşembe, 4059'40.20" N, 3746'8.25" E, 293m,

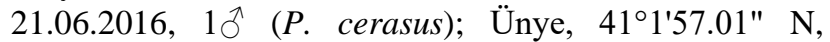
37¹9'29.87" E, 436m, 22.06.2016, 20ิ (P. domestica); Ünye, $41^{\circ} 2 ' 2.24^{\prime \prime} \mathrm{N}, 37^{\circ} 21^{\prime} 25.20^{\prime \prime} \mathrm{E}, 420 \mathrm{~m}, 22.06 .2016$,

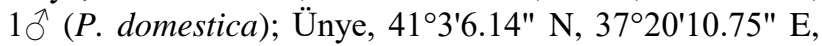

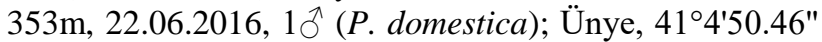
N, 37¹9'41.76" E, 120m, 22.06.2016, $2 \bigcirc^{\Uparrow}$ (P. domestica); Ünye, $41^{\circ} 0 ' 21.67^{\prime \prime} \mathrm{N}, 37^{\circ} 11^{\prime} 12.55^{\prime \prime} \mathrm{E}, 431 \mathrm{~m}, 22.06 .2016$,

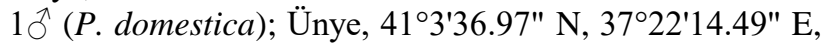

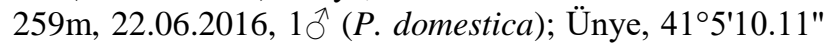


$\mathrm{N}, 37^{\circ} 12^{\prime} 32.99^{\prime \prime} \mathrm{E}, 239 \mathrm{~m}, 22.06 .2016,1 \delta^{\Uparrow}(P$. domestica) Ünye, $41^{\circ} 2^{\prime} 33.79^{\prime \prime} \mathrm{N}, 37^{\circ} 12^{\prime} 13.62^{\prime \prime} \mathrm{E}, 453 \mathrm{~m}, 22.06 .2016$ $1 \delta^{\hat{\jmath}}\left(P\right.$. domestica); Ünye, $41^{\circ} 1^{\prime} 54.48 \mathrm{~N}, 37^{\circ} 20^{\prime} 31.29^{\prime \prime} \mathrm{E}$,

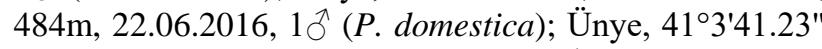

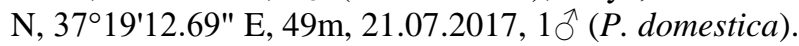

\section{Description}

Male $(\mathrm{n}=6)$ (Figure 2)

Body: Body length 261 (246-280) excluding and 321 (307-342) including gnathosoma. Dorsal setae measurements as follows: $v_{2} 44$ (42-46), $s c_{1} 73$ (71-85), $s c_{2} 45$ (42-48), $c_{1} 67$ (62-73), $c_{2} 67$ (60-71), $c_{3} 51$ (45-62), $d_{1} 66$ (60-69), $d_{2} 70$ (66-75), $e_{1} 60$ (54-65), $e_{2} 66$ (60-71), $f_{1} 44$ (40-46), f 24 (20-25), $h_{1} 22$ (18-26).

Gnathosoma: Peritreme terminates in a simple bulb (Figure 2c).

Legs: Length of legs (excluding coxae) and leg setal count as follows (solenidion provided in parentheses):

Leg I; 186 (174-194), 2 - 1 - 10 - 5 - $13-13+(3)+2$ duplexes;

Leg II; 147 (141-153), 2 - 1 - 7 - 5 - 8 - 16;

Leg III; 155 (142-164), 1 - 1 - 4 - 4 - 6 - 11;

Leg IV; 184 (174-197), 1 - 1 - 4 - 4 - 7 - 10.

Duplex setae are adjacent on tarsi I (Figure 2a). On leg I of the male, only empodium I is claw like. However, in this genus the empodium is not claw-like and split distally in 3 pairs of hairs. In the male, only empodium I (or both empodia I and II) can be claw-like.

Aedeagus: Aedeagus short, knob extended distally $(2.2 \mu \mathrm{m})$. Anterior and posterior projections angulate, posterior projection sharply pointed, knob directed dorsally with a slight angle to shaft (Figure 2b).

\section{Remarks:}

Females of E. rubiphilus are greenish yellow. Dorsal setae are longer than between their bases. Dark feeding spots are present on both sides of hysterosoma. Webs seen rarely. In fact webbing is difficult to see but present between the main vein and the leaf surface. It constitutes a sort of roof. Males are light yellow. The eggs have a small apical tip (Gutierrez and Helle, 1983).

This species is distributed in the Palearctic region and present in Georgia, Armenia and Syria neighbors of Turkey (Migeon and Dorkeld, 2019).

To date, it was reported from host plants belonging to Compositae, Rosaceae and Vitaceae (Migeon and Dorkeld 2019). Which are as follows; Alchemilla erythropoda Juz. (Reck, 1948), Potentilla fragarioides L. (Lee, 1989), Prunus spinosa L. (Migeon, et al., 2007), Rubus caesius L., Rubus fruticosus L. (Migeon, et al., 2007; Migeon, 2015; Zriki et al., 2015); Rubus ulmifolius L. (Ferragut and Escudero, 1996; Migeon, 2015) (Rosaceae), Vitis sp. (Migeon et al., 2004), Vitis vinifera L. (Migeon et al., 2007) (Vitaceae).

In this study, E. rubiphilus was collected together with the following predators: Phytoseius finitimus Ribaga, Euseius finlandicus (Oudemans), Typhlodromus tiliae Oudemans (Mesostigmata; Phytoseiidae), Cunaxoides lootsi Den Heyer \& Castro (Trombidiformes; Cunaxidae), Tydeus californicus (Banks), T. goetzi Schruft (Trombidiformes; Tydeidae) and Homeopronematus sp. (Trombidiformes; Iolinidae) from $P$. domestica.

According to the references, obtained tydeoid mites, $T$. californicus, T. goetzi (Baker and Wharton, 1952; Gerson et al., 2003; Walter and Proctor, 2013) and
Homeopronematus sp. (Zhang, 2003; Hoy, 2011) were accepted as predator.

These species may be potential predators of the $E$. rubiphilus. The predation capability of these species should be studied. Nothing is also known about biology of E. rubiphilus and this issue should also be addressed in future studies.

\section{Acknowledgments}

We are thankful to Dr. Philippe Auger (INRA, France) for his deep review and identifications of the tetranychid species. Also many thanks to Prof. Dr. Eddie A. Uckermann (North-West University, South Africa) and Prof. Dr. Sultan Çobanoğlu (Ankara University, Turkey) for confirmation of species identification and some of identifications of the tydeoid and phytoseiid species, respectively. We are very grateful to the editor and anonymous reviewers for their constructive comments which help us improve the quality of our paper.

\section{References}

Altinçag R, Akten T. 1993. Insect pests in grapevine nurseries and remedies in Aegean Region and their solutions. Bitki Koruma Bulteni, 33 (3/4): 153-165.

Auger P, Migeon A, Fletchmann CHW. 2003. A new species of Eotetranychus from France (Acari, Prostigmata: Tetranychidae). Zootaxa, 206, 1-7.

Aydemir M, Toros S. 1992. The effects of different bean varieties on the life duration and egg productivity of Tetranychus urticae Koch. (Acarina, Tetranychidae). Proceedings of the Second Turkish National Congress of Entomology. Ege Universitesi, Izmir, Turkey.

Baker EW, Wharton GW. 1952. An Introduction to Acarology. The Macmillan Company New York, USA, 465pp.

Cobanoglu S. 1989a. Antalya ili sebze alanlarında tespit edilen Phytoseiidae Berlese, 1915 (Acarina: Mesostigmata) türleri. Bitki Koruma Bülteni, 29 (1-2): 47-64.

Cobanoglu S. 1989b. Türkiye'nin bazı turunçgil bölgelerinde tespit edilen faydalı akar (Acarina: Phytoseiidae) türleri. Türkiye Entomoloji Dergisi, 13 (3): 163-178.

Cobanoglu S. 1989c. Türkiye için üç yeni faydalı akar (Acari: Phytoseiidae) türü. Türkiye Entomoloji Dergisi, 13 (4): 229-38.

Cobanoglu S. 1993a. Türkiye'nin önemli elma bölgelerinde bulunan Phytoseiidae (Parasitiformes) türleri üzerinde sistematik çalışmalar I. Türkiye Entomoloji Dergisi, 17 (1): 41-54.

Cobanoglu S. 1993b. Türkiye'nin önemli elma bölgelerinde bulunan Phytoseiidae (Parasitiformes) türleri üzerinde sistematik çalışmalar II. Türkiye Entomoloji Dergisi, 17 (2): 99-116.

Cobanoglu S. 1993c. Türkiye'nin önemli elma bölgelerinde bulunan Phytoseiidae (Parasitiformis) türleri üzerinde sistematik çalışmalar III. Türkiye Entomoloji Dergisi, 17 (3): 175-192.

Cobanoglu S. 1993d. Türkiye'nin önemli elma bölgelerinde bulunan Phytoseiidae (Parasitiformis) türleri üzerinde sistematik çalışmalar IV. Türkiye Entomoloji Dergisi, 17 (4): 239-255.

Cobanoglu S, Ueckermann EA, Kumral NA. 2015. A new Tetranychus Dufour (Acari: Tetranychidae) associated with Solanaceae from Turkey. Turkish Journal of Zoology, 39: 565-570.

Doker I, Kazak C, Karut K. 2016. Contributions to the Phytoseiidae (Acari: Mesostigmata) fauna of Turkey: morphological variations, twelve new records, re-description of some species and a revised key to the Turkish species. Systematic \& Applied Acarology, 21(4): 505-527. 
Duzgunes Z. 1954. Taxonomic and biological studies on the species of the family Tetranychidae, damaging fruit trees in Central Anatolia Ankara (Entomol. Inst.). Ziraat Vekaleti Neşriyat ve Haberleşme Müdürlüğü, 706.

Duzgunes Z. 1959. Tetranychus tumidellus "Yerfistığı akarı". Bitki Koruma Bülteni, 1: 10-14.

Duzgunes Z. 1962. Pamuk akarları (kırmızı örümcekler). Türkiye Ziraatina Zararlı Olan Böcekler ve Mücadelesi, 6, 70-77.

Duzgunes Z. 1963. Türkiye'de yeni bulunan akarlar. Bitki Koruma Bülteni, 3(4): 237-246.

Duzgunes Z. 1965. The variation in the peritreme of the genus Eotetranychus Oud. Bollettino di Zoologia Agraria e di Bachicoltura, 7:15-18.

Ehara S. 1956. Tetranychoid Mites of Mulberry in Japan. Journal of the Faculty of Science, Hokkaido University, VI, Zool. 12.

Faraji F, Cobanoglu S, Cakmak I. 2011. A checklist and a key for the Phytoseiidae species of Turkey with two new species records (Acari: Mesostigmata). International Journal of Acarology, 37 (suppl.1): 221-243.

Ferragut F, Escudero A. 1996. Dos tetraníquidos (Acari: Tetranychidae) nuevos para la fauna ibérica. Boletin de la Asociacion Espanola de Entomologia, 20, 127.

Gerson U, Smiley RL, Ochoa R. 2003. Mites (Acari) for pest control. Blackwell Science Publishing Ltd, Oxford, UK, $558 \mathrm{pp}$.

Hoy MA. 2011. Agricultural acarology: Introduction to integrated mite management. CRC Press Taylor \& Francis Group, Boca Raton, pp. 392.

Kasap İ, Polat B, Kok S. 2014. The important pest and predatory mites species (Acari) and their population fluctuation in the vineyards of Çanakkale Province. Turkish Journal of Entomology, 38 (4): 451-458.

Kazak C, Döker İ, Karut K. 2017. First record of invasive tomato spider mite Tetranychus evansi (Acari: Tetranychidae) in Turkey. International Journal of Acarology, 43 (4): 325-328.

Krantz GW, Walter DE. 2009. A Manual of Acarology. 3rd Edition. Texas Tech University Press, Lubbock, $807 \mathrm{p}$.

Lee JS. 1989. A systematic study on the Tetranychoid mites (Order: Acarina) in Korea. Chonju, Chonbuk University, $124 \mathrm{p}$.

Lindquist EE. 1985. External anatomy. In: Spider Mites: Their Biology, Natural Enemies, and Control. Helle, W., Sabelis, M.W., (Eds.). Vol. 1A. Amsterdam, the Netherlands: Elsevier, 3-28p.

Maric I, Marcic D, Petanovic R, Auger P. 2017. Biodiversity of spider mites (Acari: Tetranychidae) in Serbia: a review, new records and key to all known species. Acarologia, 58(1): 3-14.

Migeon A, Cros-Arteil S, Navajas M. 2004. The use of taxonomical and ecological databases combined with the genetic approach for tracking spidermite invasions. In: Acarine biodiversity in the natural and human sphere. Weigman, G., Alberti, G., Wolhtmann, A., Ragusa, S., (Eds.). Berlin, Phytophaga, 14: 757-765 p.
Migeon A, Malagnini V, Navajas M, Duso C. 2007. Notes on the genus Eotetranychus (Acari: Tetranychidae) in Italy and France with a redescription of Eotetranychus fraxini Reck, new record for Italy and Western Europe. Zootaxa, 1509: 51-60.

Migeon A. 2015. The Jean Gutierrez spider mite collection. Zookeys, 489: 15-24.

Migeon A, Dorkeld F. 2019. Spider Mites Web: a comprehensive database for the Tetranychidae. Available from: http://www.montpellier.inra.fr/CBGP/spmweb (1.11.2018).

Murase A, Fujita K. 2018. Predator experience changes spider mites' habitat choice even without current threat. Scientific reports, 8,8388 .

Nishimura S, Hinomoto N, Takafuji A. 2007. The population genetic structure of Tetranychus kanzawai Kishida (Acari: Tetranychidae) in Northern Hokkaido, Japan, as estimated using microsatellite polymorphism. Journal of the Acarological Society of Japan, 16 (1): 11-20.

Osakabe M. 1967. Biology and controlling methods of Tea red spider mite, Tetranychus kanzawai Kishida, in Japan. The Bulletin of the Tea Research Station. Ministry of Agriculture and Forestry, 4: 22-24.

Onucar A, Ulu O. 1988. Kestane ağaçlarında bulunan akar türleri hakkında kısa bilgiler. Türkiye Entomoloji Dergisi, 12 (1), 33-38.

Ozman SK, Cobanoglu S. 2001. Current status of hazelnut mites in Turkey. Acta Horticulture, 556, 479-487.

Ozsisli T, Cobanoglu S. 2011. Mite (Acari) Fauna of some cultivated plants from Kahramanmaraş, Turkey. African Journal of Biotechnology, 10 (11): 2149-55.

Reck GF. 1948. Descriptions of species of the genus Schizotetranychus (Träg.) from Georgia. Soobshcheniya Akademii Nauk Gruzinskoi SSR, 9, 445-452.

Ripka, G, Laniecka I, Kaźmierski A. 2013. On the arboreal acarofauna of Hungary: Some new and rare speciesof prostigmatic mites (Acari: Prostigmata: Tydeidae, Iolinidae and Stigmaeidae). Zootaxa, 3702(1): 1-50.

Seeman OD, Beard JJ. 2011. A new species of Aegyptobia (Acari: Tenuipalpidae) from Myrtaceae in Australia. Systematic and Applied Acarology, 16: 73-89.

Ueckermann, EA. 2013.Course on taksonomy of the Tydeoidae, $\mathrm{s}: 24$.

Uysal C, Cobanoglu S, Okten ME. 2001. Determination of Tetranychoidea (Acarina: Prostigmata) species harmful in the park areas of Ankara. Türkiye Entomoloji Dergisi, 25: 147-160.

Walter DE, Proctor HC. 2013. Mites: ecology, evolution \& behaviour. Springer Science+Business Media Dordrecht, 494pp.

Yanar D, Ecevit O. 2005 Tokat ilinde elma (Malus communis L.) bahçelerinde görülen bitki zararlisi ve predator akar türleri. Ondokuz Mayıs Üniversitesi Ziraat Fakültesi Dergisi, 20 (1): 18-23.

Zhang ZQ. 2003. Mites of Greenhouses: Identification, Biology and Control. CABI Publishing, Wallingford, UK, 7, 244 pp.

Zriki G, Shaabo A, Boubou A. 2015. A preliminary survey of the spider mites (Acari: Tetranychidae) in Latakia Governorate of Syria. Acarologia, 55 (3): 303-309. 